\title{
EDUCATION OF LOCAL WISDOM TO PREVENT FOREST FIRES IN RIAU PROVINCE: CHALLENGES, POTENTIALS, AND SOLUTIONS
}

\author{
Rian Vebrianto \\ Fakultas Tarbiyah dan Keguruan \\ Universitas Islam Negeri Sultan Syarif Kasim Riau \\ rhayent23ukm@gmail.com \\ Zarkasih \\ Fakultas Tarbiyah dan Keguruan \\ Universitas Islam Negeri Sultan Syarif Kasim Riau \\ zarkasih@uin-suska.ac.id
}

\begin{abstract}
Forest fires are one of the most frequent environmental problems in Riau province, which often comes in large scale; thus, they cause forest degradation that damages economic, ecological and social aspects. The forest fires in Riau primarily caused by weak. regulations and their enforcement and the lack of an optimum system or institutional mechanisms to address this issue. One alternative solution that is often forgotten is the role of education in forest fires prevention, particularly in the education of local wisdom. The education is required to minimize the risk of forest and land fires; hence it could be used a reference for the Riau government. This study aimed to identify and analyze local wisdom in the community to prevent forest and land fires, including the challenges, potentials, and solutions.
\end{abstract}

Keywords: local wisdom, smoke disaster, education

\section{PENDAHULUAN}

Riau memiliki semboyan "Bumi Bertuah Negeri Beradat". Bumi bertuah ini memiliki makna negeri yang konon merupakan Jamrud khatulistiwa yang sebenarnya, di kenal dengan "land of paradise" bak kata koes plus "Tongkat kayu jadi Tanaman". Jamrud artinya permata hijau atau benda yang indah, sedangkan khatulistiwa adalah daerah tropis. Sehingga dapat disimpulkan bahwa provinsi Riau adalah daerah tropis yang penuh keindahan dan keberagaman flora dan fauna serta memiliki hutan tropis yang rimbun dan hijau bak permata. Negeri beradat dipimpin oleh Datuk Sri Setia Amanah dengan memegang adat yang kuat. Adat ini juga berfungsi sebagai kontrol dan local Wisdom bagi masyarakat dalam menjaga lingkungannya.

Dari semboyan diatas, nampaklah dengan jelas potensi Provinsi Riau sebagai Jamrud khatulistiwa dimana Hutan mengambil peranan yang sangat penting sebagai paru-paru dunia, melalui proses fotosintesis hutan tersebut, akan mengambil karbondioksida dan akan melepaskan oksigen yang segar dan sehat bagi keperluan makhluk hidup yang ada di dalamnya termasuk juga untuk keberlangsungan umat manusia. Hutan juga berfungsi menjaga agar tidak longsor dan banjir. Sesungguhnya menjaga kelestarian hutan sama saja dengan menjaga 
kelestarian flora dan fauna termasuk juga kelestarian Umat Manusia. Dengan terjaganya lingkungan keasrian hutan, maka terjagalah biodiversitas dari flora dan fauna yang juga menjadikan sebuah peluang sektor objek wisata alam yang sangat menjanjikan.

Provinsi Riau memiliki sektor wisata alam dan wisata religi, budaya dan sejarah yang menjanjikan dan menjadi promosi dan kebanggaan di ajang Nasional maupun di tingkat International (mendunia) diantaranya untuk wisata alam yaitu objek wisata bono di Pelalawan, pulau jemur di Rokan Hilir, pantai solop di Indragiri Hilir, pantai rupat utara tanjung medang, Taman nasional bukit tiga puluh. Dan baru baru ini, ditemukan tempat wisata di daerah kampar "Ulu kasok" si Raja Empatnya Riau, dan masih banyak lagi lainnya. Di sektor wisata religi, budaya dan sejarah diantaranya: istana siak di kabupaten Siak, Upacara bakar tongkang di Rokan Hilir, perayaan imlek di Selat panjang, candi muara takus di kabupaten Kampar, serta baru baru ini juga minat dan animo masyarakat untuk antusias datang ke islamic center mesjid madani di kabupaten Rokan hulu. Maka nikmat Tuban Manakah lagi yang kamu dustakan? (Q.S. ArRahman: 13).

Bagaimana Nasib Riau sebagai jamrud khatulistiwa kini? Ironis memang, dengan adanya alih hutan yang begitu masif dan besar-besaran yang disertai keserakahan manusia, mengakibatkan adanya tindakan pembakaran hutan, dan illegal loging serta rendahnya kontrol dan tegaknya hukum, selama beberapa puluh tahun belakangan ini. Negeri yang semula menjadi syurga bagi manusia kini telah berubah menjadi Neraka. Hutan yang seharusnya memberikan oksigennya kini menangis dan tertatih mengeluarkan gas beracun dalam bentuk Asap. Tahun 2015, ASAP masih menjadi bencana terbesar bagi umat manusia di Riau, beberapa ratus orang diungsikan, sistem pembelajaran sekolah dan perkantoran terganggu, jarak pandangpun hanya $1 \mathrm{~km}$ yang menganggu penerbangan yang pastinya ikut serta menganggu perkembangan sektor pariwisata secara langsung bahkan Asappun sampai ke negara tetangga Malaysia dan Singapura. Bencana ini tidak hanya merugikan secara materil tetapi juga moril bagi keberlangsungan umat manusia. Dilihat dari sektor Pariwisata, sudah mulai nampak pembenahan meskipun dalam pengelolaannya perlu adanya kontrol dan perawatan serta menambah fasilitas yang diperlukan ditempat wisata tersebut (Rian Vebrianto, 2017; Husni Tamrin 2013)

Jadi, Apa yang harus kita perbuat?

Perlu adanya "Revitalisasi dan eksplorasi nilai-nilai kearifan lokal dan sains serta agama dalam model sistem pembelajaran yang diimplementasikan kedalam lingkungan sekolah dan masyarakat dalam mengatasi bencana asap dan memajukan sektor pariwisata di Riau" (Vebrianto, 2017; Husni Tamrin 2013; Syaufina dan Tambunan 2013; Erwan baharudin 2012; Suyanto et al. 2003). 
Rian Vebrianto dan Zarkasih: Education Of Local Wisdom...

Isu Pembakaran Hutan Di Riau

Sebagai suatu ekosistem, lingkungan hidup mempunyai aspek sosial, budaya, ekonomi dan geografi dengan corak ragam dan daya dukung yang berbeda Politik pembangunan terutama di negara-negara berkembang yang lebih menitikberatkan pada pertumbuhan ekonomi untuk mengejar kesejahteran rakyat sering mendatangkan permasalahan di bidang lingkungan. Permasalahan lingkungan ini biasanya bersumber pada dorongan untuk memanfaatan secara terus menerus dan belebihan sumber daya alam tanpa memperhatikan daya dukung sumber daya alam tersebut. Untuk mengejar kemakmu-ran, sumber daya alam dipandang sebagai faktor produksi untuk mewujudkan tujuan pembangunan ekonomi, tanpa memperhatikan dampaknya (Erwan baharudin 2012). Sumber daya alam, seperti air (air darat dan air laut), tanaman atau hutan, binatang, tanah, dan udara nasibnya sangat tergantung pada moralitas manusia (Husni Tamrin 2013)

Secara ilmiah, hutan memiliki fungsi yang amat penting Salah satunya sebagai melindungi dan menjaga ekosistem baik pada tingkat lokal, regional, maupun global. Fungsi lainya adalah sebagai \produktivitas komoditas, menjaga keanekaragaman hayati (biodiversity), dan menyerap karbon dioksida yang terperangkap dalam atmosfer. Penyusutan hutan secara besarbesaran, karena itu, dapat menyebabkan lingkungan rentan terhadap bencana (Husni Tamrin 2013)
Akhir-akhir ini alam di Indonesia banyak mengalami perubahan lingkungan, banyak musibah seperti kebakaran hutan, Asap, banjir besar, tanah longsor, satwa yang menyerang manusia. Jika lingkungan yang sekarang ini dibandingkan dengan 20 tahun yang lalu, terjadi perbedaan yang sangat timpang, dimana terasa sekali kerusakan alam yang terjadi. Hal ini sesuai dengan yang disampaikan Kepala Pusat Data Informasi dan Humas Badan Nasional Penanggulangan Bencana (BNPB), Sutopo Purwo Nugroho (2015) dalam Republika.co.id, tertanggal 14/9/2015. mengatakan asap dari kebakaran hutan dan lahan di Sumatera dan Kalimantan, masih mengepung banyak wilayah. Berdasarkan pantau satelit Terra dan Aqua, hotspot di Sumatera sebanyak 1.143 titik yaitu di Bengkulu 13, Jambi 234, Lampung 69, Riau 78, Sumbar 25, dan Sumsel 724. Sementara hotspot di Kalimantan 266 titik yaitu di Kalbar 26, Kalsel 74, Kalteng 164 dan Kaltim 2. Dengan jarak pandang hanya 80-800 m.

Secara spesifik, di Pekanbaru jarak pandang $200 \mathrm{~m}$, Rengat $70 \mathrm{~m}$, Dumai dan Pelalawan 50 m, Jambi 700 m, Palembang $800 \mathrm{~m}$. Jarak pandang di Kalimantan 100-600 m, di Pontianak 600 m, Ketapang 600 m, Sintang 300 m, Nanga Pinoh 500 m, Pangkalan Bun 500 m, Sampit 300 m, Palangkaraya 400 m, Sanggu Buntok 100 m, Banjarmasin 220 m.

Efek dari itu semua, Kebakaran hutan merupakan salah satu masalah lingkungan yang sering terjadi yang dalam skala besar merupakan salah satu penyebab degradasi hutan dan 
terbukti menimbulkan kerusakan dan kerugian baik pada aspek ekonomi, ekologi, maupun sosial. Secara genetik, krisis lingkungan dari bencana kebakaran mencakup air, tanaman, binatang, tanah, dan udara. Hal-hal yang telah disebut itu mengalami krisis karena tercemar oleh tiga teknologi utama, yaitu: teknologi industri, teknologi tranportasi, dan teknologi energi, di samping tentu saja kecerobohan manusia di alam pengelolaan terhadap sumber daya alam itu. Selain itu, krisis lingkungan juga disebabkan oleh pertumbuhan penduduk yang pesat dan pengangguran akan diikuti oleh permintaan terhadap ketersediaan sumberdaya alam (SDA), kebijakan pemerintah, Dampak Industrialisasi, Reboisasi dan Reklamasi yang gagal Apalagi bila degradasi SDA dan percemaran yang terjadi jauh lebih tinggi dibandingkan laju upaya perbaikannya, lemahnya penegakan hukum serta kesadaran masyarakat yang rendah (Hadi S. Alikodra, 2009; Erwan Baharudin 2012; Husni Tamrin 2013; Vebrianto \& kamisah 2011).

\section{Isu Landasan berkaitan dengan kearifan budaya Lokal}

Banyak hal yang melandasi adanya kearifan budaya lokal yang dapat dilihat dari landasan historis, Psikologis, komunikasi dan politik, serta yuridis.

\section{a. Landasan Historis}

Kearifan lokal dapat bersumber dari kebudayaan masyarakat dalam suatu lokalitas tertentu. Dalam perspektif historis, kearifan lokal dapat membentuk suatu sejarah lokal. Sebab kajian sejarah lokal yaitu studi tentang kehidupan masyarakat atau khususnya komunitas dari suatu lingkungan sekitar tertentu dalam dinamika perkembangannya dalam berbagai aspek kehidupan. Awal pembentukan kearifan lokal dalam suatu masyarakat umumnya tidak diketahui secara pasti kapan kearifan lokal tersebut muncul. Pada umumnya terbentuk mulai sejak masyarakat belum mengenal tulisan (praaksara). Tradisi praaksara ini yang kemudian melahirkan tradisi lisan (Ayatrohaedi, 1986).

Secara historis tradisi lisan banyak menjelaskan tentang masa lalu suatu masyarakat atau asal-usul suatu komunitas. Perkembangan tradisi lisan ini dapat menjadi kepercayaan atau keyakinan masyarakat. Dalam masyarakat yang belum mengenal tulisan terdapat upaya untuk mengabadikan pengalaman masa lalunya melalui cerita yang disampaikan secara lisan dan terus menerus diwariskan dari generasi ke genarasi. Pewarisan ini dilakukan dengan tujuan masyarakat yang menjadi generasi berikutnya memiliki rasa kepemilikan atau mencintai cerita masa lalunya. Tradisi lisan merupakan cara mewariskan sejarah pada masyarakat yang belum mengenal tulisan, dalam bentuk pesan verbal yang berupa pernyataan yang pernah dibuat di masa lampau oleh generasi yang hidup sebelum generasi yang sekarang ini.

b. Landasan Psikologis 
Rian Vebrianto dan Zarkasih: Education Of Local Wisdom...

Secara psikologis pembelajaran berbasis kearifan lokal memberikan sebuah pengalaman psikologis kepada siswa selaku pengamat dan pelaksana kegiatan. Dampak psikologis bisa terlihat dari keberanian siswa dalam bertanya tentang ketidaktahuannya, mengajukan pendapat, persentasi di depan kelas, dan berkomunikasi dengan masyarakat. Dengan pemanfaatan lingkungan maka kebutuhan siswa tentang perkembangan psikologisnya akan diperoleh. Karena lingkungan merupakan salah satu faktor yang mempengaruhi pembentukan dan perkembangan perilaku individu, baik lingkungan fisik maupun lingkungan sosiopsikologis, termasuk didalamnya adalah belajar. Terhadap faktor lingkungan ini ada pula yang menyebutnya sebagai empirik yang berarti pengalaman.

\section{c. Landasan Politik dan Ekonomi}

Secara politik dan ekonomi pembelajaran berbasis kearifan lokal ini memberikan sumbangan kompetensi untuk mengenal persaingan dunia kerja. Dari segi ekonomi pembelajaran ini memberikan contoh nyata kehidupan sebenarnya kepada siswa untuk mengetahui kegiatan untuk memenuhi kebutuhan hidup. Karena pada akhirnya siswa dididik dan disiapkan untuk menghadapi persaingan global yang menuntut memiliki ketrampilan dan kompetensi yang tinggi di lingkungan sosial.

\section{d. Landasan Yuridis}

Secara yuridis pembelajaran berbasis kearifan lokal mengarahkan peserta didik untuk lebih menghargai warisan budaya Indonesia. Sekolah Dasar tidak hanya memiliki peran membentuk peserta didik menjadi generasi yang berkualitas dari sisi kognitif, tetapi juga harus membentuk sikap dan perilaku peserta didik sesuai dengan tuntutan yang berlaku. Apa jadinya jika di sekolah peserta didik hanya dikembangkan ranah kognitifnya, tetapi diabaikan afektifnya. Tentunya akan banyak generasi penerus bangsa yang pandai secara akademik, tapi lemah pada tataran sikap dan perilaku. Hal demikian tidak boleh terjadi, karena akan membahayakan peran generasi muda dalam menjaaga keutuhan bangsa dan Negara Indonesia. Nilai-nilai kearifan lokal yang ada di sekitar sekolah dapat dimanfaatkan untuk pembelajaran di Sekolah Dasar. Tak terkecuali dalam pembelajaran untuk menanamkan nilainilai nasionalisme. Dengan diintegrasikannya nilai-nilai kearifan lokal dalam pembelajaran di Sekolah Dasar diharapkan siswa akan memiliki pemahaman tentang kerifan lokalnya sendiri, sehingga menimbulkan kecintaan terhadap budayanya sendiri.

Local genius merupakan istilah yang mula pertama dikenalkan oleh Quaritch Wales. Para antropolog membahas secara panjang lebar pengertian local genius ini (Ayatrohaedi, 1986). Antara lain Haryati Soebadio mengatakan bahwa local genius adalah juga cultural identity, identitas/kepribadian budaya bangsa yang menyebabkan bangsa tersebut mampu menyerap dan mengolah kebudayaan asing sesuai watak dan kemampuan sendiri). 
Sementara (Ayatrohaedi, 1986) mengatakan bahwa unsur budaya daerah potensial sebagai local genius karena telah teruji kemampuannya untuk bertahan sampai sekarang. Ciri-cirinya adalah: (a)mampu bertahan terhadap budaya luar, (b) memiliki kemampuan mengakomodasi unsur-unsur budaya luar, (c) mempunyai kemampuan mengintegrasikan unsur budaya luar ke dalam budaya asli, (d) mempunyai kemampuan mengendalikan, dan (e) mampu memberi arah perkembangan budaya. Mengacu pada kedua pengertian tersebut cukup beralasan jika kemudian kemendikbud menyebut keduanya sebagai keunggulan lokal.

\section{Isu Dari Pelaksanaan Kurikulum Formal}

Menurut Santosa (2015) Setidaknya ada 8 kodrat atau fitrah yang gagal di bangkitkan dan rentan hilang dan menyimpang atau terkubur akibat dari penerapan yang hanya melibatkan kurikulum formal dan seragam persekolahan yaitu;

\section{a. Kodrat/fitra beragama}

Agama sudah di pisahkan dari moral dan kehidupan bahkan tidak pernah menyatu dengan sains. Ketika orang berbicara tentang agama, maka seolah agama hanya kumpulan ibadah ritual yang menolak dunia, menolak sains dan disisi ekstrim lainnya ada yang percaya bahwa agama adalah hasil pengalaman hidup dan kebudayaan manusia. Untuk itu perlu pengintegrasian keilmuan yang makin menguatkan keimanan sesorang yang mencintai ilmu dan perkembangan zaman.

\section{b. Kodrat/fitra belajar}

Kodrat ini umumnya hilang sejak dari hilangnya gaira belajar, gaira menalar, kesukaan meneliti, konstruksi nalar sampai kepada gairah inovasi, umumnya anak kita belajar karena ada ujian, karena di suruh, karena ada silabus, karena ingin juara, karena ingin rengking atau hadiah atau gelar danseterusnya. Para maha siswa membuat skripsi sebagai karya terakhir dan satu-satunya sepanjang hidupnya. Kebanyakan guru juga hilang fitrah belajarnya dan nalarnya karena belajar harus sesuai tupoksi, karena motivasi naik jabatan, karena sertifikasi dll. Makanya perlu juga belajar dengan "back to nuture" dimana belajar adalah sebuah anugrah dan saranan yang menyenangkan dekat dengan alam untuk menghadirkan pemimpin dimasa depan yang siap mengemban amanah menjaga bumi dari kerusakan dan pengembangan kelestaraian alam sekitar jauh dari sikap sombong dan serakah serta berlebih-lebihan.

c. Kodrat/fitrah bakat

Umumnya anak kita jarang diamati sifat bawaannya, tidak diberi kesempatan aktivitas yang relevan demgan bakatnya, bahkan sampai peran profesionalnya kelak yang tidak nyambung dengan potensi bakat atau jati dirinya. Umumnya bakat dianggap ekskul dan hanya terkait bidang-bidang olah raga saja. Untuk itu kedekatan dengan alam dapat dengan sendirinya memancing timbul imajinasi dan pemikiran serta bakat otentik siswa yang seyogyanya harus dimiliki dalam proses 
Rian Vebrianto dan Zarkasih: Education Of Local Wisdom...

keterampilan bertahan hidup. Keseimbangan alam memberikan kesempatan bagi siswa atau anak untuk berfikir akan keterkaitan dan jaringan untuk kemudian berpengaruh terhadap pemikiaran dan bakatnya.

d. Kodrat/fitrah perkembangan

Tahapan perkembangan anak gagal diintegrasikan dengan tahapan persekolahan. Misalnya PAUD di jadikan ajang persiapan masuk SD, bukan agar anak kita utuh menjadi usia dini saat tahap usia dini dan sebagainya. Kedewasaan yang dilambatkan atau pembocahan yang panjang (infantization) berupa kelas remaja berusia 12-24 tahun yang galau dan rentang penyimpangan, adalah rekayasa sosial untuk memperlambat kelas produktif dan generasi aqil balik demi kepentingan industri. Seharusnya perkembangan dibebankan sesuai dengan tingkatan aqil balik seseorang yang mana dengan adanya kesesuaian setiap perkembangan anak/siswa maka akan menstimulus dengan sendirinya keseimbangan dengan alam. Misalnya banyak sekali contoh para nabi yang telah diserahkan tanggung jawab untuk mengelola domba atau kambing, dalam proses pengelolaan yang dilakukan maka sebelum menjadi seorang nabi maka mereka akan bijak dan memhami keterkaitan alam dan rasa syukur yang besar kepada Allah SWT.

\section{e. Kodrat/fitrah seksual}

Kodrat atau fitrah kelelakian dan keayahan juga fitrah keperempuanan dan kebundaan sering kali dijumpai hilan, kasus-kasus LGBT dan penyimpangan seksual, hamil di luar nikah dan lainnya, baik bagi pelaku maupun korban, umumnya diakibatkan pendidikan fitrah seksualitas yang terlewatkan. ibu Elly Risman menyebut negeri ini the fatherless country dimana fitrah peran keayahan memudar, para ayah hanya mencari nafkah bukan lagi leader. Begitu pula fitrah kebundaan, banyak generasi kini tidak siap bahkan tidak berminat menjadi ibu. Dengan program perkemahan dan aktivitas aktivitas di alam menjauhkan kelainan dalam pergaulan seksual, anak dipenuhi kegiatan kegiatan yang sangat positif dalam menjamin berkembangnya otak dan fisik serta hati mereka menjadi satu kesatuan yang menjaganya dan digunakan untuk hal-hal yang positif.

f. Kodrat/fitrah alam atau keunggulan lokal dan keanekaragaman hayati

Potensi keunggulan lokal hanya dianggap pengetahuan muatan lokal, anak-anak desa dipastikan urban dan sepanjang hayatnya tidak tahu mengembangkan keunggulan alam dan kearifan desa dan kampungya. Makanya, wajib bagi pendidik dan orang tua mengenalkan kearifan lokal yang kita miliki dalam hal ini, melayu merupakan peradapan yang tinggi dan besar yang memberikan pengaruh terhadap kemerdekaan Indonesia ini. Dengan bahasa melayu Indonesi lahirlah bahasa Indonesia yang menyatukan. Dengan banyaknya para pujangga dan pemikir seperti "Raja ali haji" dalam gurindamnya menyampaikan pesan pesan moral dan luhur yang juga sangat terkait rapat dengan 
kehidupan kita dengan alam yang harus saling menjaga dan harmonis.

g. Kodrat/fitrah kearifan dan realitas masyarakat

Proses pendidikan atau kurikulum formal seragam umumnya tidak relevan dengan realitas sosial dan tidak mampu menjawab problematika sosial di masyarakat. Anak-anak umumnya hanya bersosial di ruang-ruang kelas dan sekolahnya, mereka tercerabut dari akar keluarga dan akar masyarakatnya. Mereka umumnya tidak memahami dinamika dan problematika masyarakat sekitarnya. Sehingga mereka menjadi acuh dan sedikit berperan dalam masyarakat. Padahal anak / siswa saat ini adalah pemimpin dan tokoh masyarakat di hari kedepannya. Keadaan yang seperti ini sebaiknya dianggap isu yang serius agar semua unsur dalam masyarakat dan pendidikan ikut serta membina kepekaan siswa dan anak terdapat lingkungan sekitar dan kehidupan yang realitas di lapangan dengan memberikan peranan peranan dan pelatihan kecil agar ikut serta mengemban tanggung jawab menjaga lingkungan yang asri.

\section{h. Kodrat/fitrah zaman}

Pendidikan umumnya tidak relevan dengan zaman. Teknologi modern digunakan namun tidak menjadi kearifan hidup di abad 21. Di barat ini disebut kecakapan abad 21 atau 21 st century skill anak-anak generasi C menggunakan gadget untuk merusak fitrahnya, bukan memanfaatkan fitrahnya. Untuk itu, perlu diberikan manajemen waktu kapan anak menggunakan gagdjetnya dan kapan anak perlu interaksi dengan lingkungannya terutama lingkungan alam yang sangat baik untuk meningkjatkanb keterampilan diri kembang anak. Seorang penemu tekhnologi cangih brand “Apple' yaitu Steve Jobs, tidak memberikan gadget ke anaknya malah membiarkan anaknya bermain dengan alam dan lumpur, karena tekhnologi itu sebenarnya sangat mudah di pelajari atau dikuasi. Tetapi kodrat artau fitrah nak dengan lingkungan itu lebih penting untiuk mengembangan segala keterampilan dan potensi yang ada pada diri anak.

model pembelajaran berbasis budaya lokal dalam hal ini merupakan kearifan lokal dapat memberikan pengaruh yang lebih baik terhadap peningkatan prestasi belajar sains siswa dibandingkan dengan menggunakan model pembelajaran dengan reguler. Hal ini disebabkan karena beberapa alasan sebagai berikut.

Pertama, dilihat dari segi landasan teoretis, model pembelajaran berbasis budaya dapat membantu siswa dalam menjembatani antara pengetahuan budaya mereka dengan sains di sekolah. Mengawali pembelajaran siswa diminta untuk mengungkapkan gagasan, ide, pengetahuan dan bahkan keyakinannya terhadap objek atau fenomena alam maupun sosial budaya di sekitar siswa yang terkait dengan pelajaran yang akandipelajari. Hal ini sesuai dengan pendapatnya Ausubel yang mentakan bahwa hal yang paling penting dalam belajar adalah apa yang telah diketahui siswa. 
Rian Vebrianto dan Zarkasih: Education Of Local Wisdom...

Hal senada juga dikemukakan oleh Herbert (2008) bahwa guru perlu menggali pandangan dan menjadikan acuan dalam belajar sains yaitu pandangan asli siswa dan pandangan ilmiah tentang dunia secara simultan dalam belajar.

Dari pengalaman peneliti, menjelaskan bahwa pandangan asli yang bertentangan dengan pemikiran sains barat tidak menghalangi pemahaman sains siswa dan bahkan pandangan asli dan pandangan ilmiah tentang dunia dimungkinkan untuk diajarkan secara simultan. Lebih lanjut, George (1995) menyatakan dua hal sebagai berikut. (1) Pada belajar kolateral paralel (parallel collateral learning), siswa dapat memiliki kedua skema yang hanya sedikit persamaannya (sains aslinya belum dapat dijelaskan sains Barat), dan akan menerima skema yang terbaik dan cocok dengan situasi yang dimilikinya

\section{Isu Integrasi Pembelajaran Sains berbasis Kearifan Budaya Lokal}

Pembelajaran sains tidak dapat menghindar dari hakikat sains itu sendiri. Sains dapat dipandang sebagai a body of knowledge, a way of thinking, and a way of investigating (Herbert 2008). A body of knowledge (sains sebagai sekumpulan pengetahuan), hasil penemuan dari kegiatan kreatif para ilmuan selama berabad-abad dikumpulkandan disusun secara sistemik menjadi kumpulan pengetahuan yang dikelompokkan sesuai dengan bidang kajiannya, misalnya fisika, biologi, kimia dan sebagainya.
Kumpulan pengetahuan tersebut berupa: fakta, konsep, prinsip, hukum, teori maupun model.

A way of investigating (sains sebagai cara penyelidikan), sains sebagai cara penyelidikan memberikan ilustrasi tentang pendekatanpendekatan yang digunakan dalam menyususn pengetahuan. Di dalam sains kita mengenal banyak metode, yang menunjukkan usaha manusia untuk menyelesaikan masalah.Sejumlah metode yang digunakan oleh para ilmuwan tersebut mendasarkan pada observasi dan prediksi,misalnya pada astronomi. Metode yang lain mendasarkan pada keinginan laboratorium atau eksperimen yang memfokuskan pada hubungan sebab akibat.

Oleh karena itu, orang yang ingin memahami fenomena alam dan hukum-hukum yang berlaku harus mempelajari objek-objek dan kejadian-kejadian di alam. Objek dan kejadian alam tersebut harus diselidiki melalui eksperimen dan observasi serta dicari penjelasannya melalui proses pemikiran untuk mendapatkan alasan atau argumentasinya. Jadi pemahaman tentang proses yaitu cara bagaimana informasi ilmiah diperoleh, diuji dan divalidasikan merupakan hal yang sangat penting dalam sains.

Mengacu pada hakikat ini, pembelajaran sains harus dapat memfasilitasi peserta didik berfikir dan berbicara serta bekerja melalui minds-on dan hands-on science. Oleh karena itu, berpikir dan berbicara melalui minds-on dan memperoleh, menguji serta memvalidasi informasi ilmiah melalui hands-on science harus 
menjadi pertimbangan utama dalam melaksanakan pembelajaran sains. Fasilitasi pembelajaran sains seperti tersebut ditempuh misalnya melalui siklus belajar sains. Siklus belajar sains, dikenalkan pertama kali oleh Karplus dan Their (Lawson, 1995) dalam buku panduan guru pada program Science Curriculum Improvement Study di sekitar awal Tahun 1970.

Siklus belajar ini dilakukan melalui tiga fase; exploration, invention, dan discovery. Tahap exploration dimaksudkan untuk memberi kesempatan pada peserta didik melakukan eksplorasi bahan-bahan atau ide-ide baru dengan bimbingan atau harapan minimal terhadap prestasi tertentu. Pada tahap ini, peserta didik bisa belajar melalui reaksi spontan mereka sendiri tentang topik baru.

Dalam tahap invention, guru mengenalkan konsep-konsep, prinsip-prinsip, dan teori-teori baru.Untuk menjelaskan hal-hal tersebut guru hendaknya merujuk pada aktivitas dalam tahap eksplorasi. Guru hendaknya juga menjelaskan penerapan gagasan baru untuk mengembangkan pengetahuan, pikiran dan keterampilan-keterampilan peserta didik. Beberapa buku rujukan menyebut tahap ini sebagai tahap pengenalan konsep.

Tahap discovery dimaksudkan untuk memberi kesempatan pada peserta didik menerapkan konsep-konsep, prinsip-prinsip, dan teori-teori dalam situasi baru.Aktivitasaktivitas peserta didik dalam tahap ini hendaknya juga memasukkan analisis teoritik konsep-konsep, prinsip-prinsip, atau teori-teori untuk memperkuat pemahaman mereka. Dalam beberapa buku rujukan, tahap discovery disebut tahap application.

\section{RUMUSAN MASALAH}

Adapun Rumusan masalah dalam jurnal ini adalah:

1. Bagaimanakah peranan kearifan lokal dalam mengatasi Bencana Alam khususnya bencana Asap dilihat dari Tantangan, Potensi dan solusi Di Provinsi Riau?

\section{TUJUAN PENELITIAN}

Penelitian ini bertujuan untuk mengidentifikasi dan menganalisis kearifan lokal dalam pencegahan kebakaran hutan dan lahan dilihat dari sisi tantangan, potensi dan solusi.

\section{METODOLOGI PENELITIAN}

Penelitian ini merupkan penelitian kajian literatur (study literatur) dengan mengkaji bukubuku teks dan naskah publikasi yang bersumber dari naskah yang relevan dengan permasalahan yang dijadikan topik penelitian ini. Metode analisis yang digunakan adalah meta analisis. Dengan meta analisis diharapkan dapat memperoleh data yang komprehensif dan mendalam. Langkah-langkah yang dilakukan diantaranya pengumpulan data pustaka, membaca dan mencatat, serta membandingkan literatur untuk kemudian diolah dan menghasilkan kesimpulan dan ide baru. Data 
Rian Vebrianto dan Zarkasih: Education Of Local Wisdom...

yang digunakan merupakan data sekunder yang berasal dari textbook, jurnal, artikel ilmiah, literature review yang berisikan tentang konsep yang diteliti.

\section{HASIL PENELITIAN DAN PEMBAHASAN}

Dalam hasil penelitian ini disajikan secara lugas dan jelas berkaitan dengan peluang atau potensi dari kearifan lokal. Dalam artikel ini terdapat dua landasan implementasi dari peluang tersebut. Di sekolah dan diluar sekolah yang merupakan sebuah sistem dalam tatanan kehidupan yang diharapkan memberikan kesan yang positif dalam menjaga keseimbangan makhluk hidup khususnya pelestarian hutan hingga keanak cucu.

\section{Pendidikan berbasis kearifan Lokal di Sekolah}

Pembelajaran berbasis keunggulan/kearifan lokal tidak muncul begitu saja, akan tetapi terdapat acuan yang melandasinya. Acuan yang digunakan setidaknya pada dua hal, yaitu pembelajaran sebagai salah satu aspek pemenuhan tujuan pendidikan dan landasan yuridis kebijakan nasional pendidikan. Pendidikan adalah program pembelajaran, secara singkat merupakan elemen dasar perubahan perilaku (pendidikan) yang berlangsung baik di dalam maupun di luar kelas sebagai interaksi antara pebelajar, pengajar dalam lingkungan tertentu.
Landasan yuridis kebijakan nasional tentang pendidikan berbasis keunggulan lokal (PBKL) sebagaiu Potensi penting terlaksannya program pembelajaran di sekolah yang berbasis kearifan lokal, diantaranya:

(a) Peraturan Pemerintah Nomor 19 tahun 2005 BAB III pasal 14 ayat 1, bahwa "Untuk SMA/MA/SMALB atau bentuk lain yang sederajat dapat memasukkan pendidikan berbasis kearifan lokal",

(b) Peraturan Pemerintah Nomor 17 Tahun 2010 pasal 34, bahwa "Pendidikan berbasis keunggulan lokal adalah pendidikan yang diselenggarakan setelah memenuhi Standar Nasional Pendidikan dan diperkaya dengan keunggulan kompetitif dan/atau komparatif daerah",

(c) Peraturan Pemerintah Nomor Nomor 17 Tahun 2010 pasal 35 ayat 2, bahwa "Pemerintah kabupaten/kota melaksanakan dan/atau memfasilitasi perintisan program dan/atau satuan pendidikan yang sudah atau hampir memenuhi Standar Nasional Pendidikan untuk dikembangkan menjadi program dan/atau satuan pendidikan bertaraf internasional dan/atau berbasis keunggulan lokal", dan

(d) Renstra Kemendiknas 2010-2014 bahwa: Pendidikan harus menumbuhkan pemahaman tentang pentingnya keberlanjutan dan keseimbangan ekosistem, yaitu pemahaman bahwa manusia adalah bagian dari ekosistem. Pendidikan harus memberikan pemahaman tentang nilai-nilai 
tanggung-jawab sosial dan natural untuk memberikan gambaran pada peserta didik bahwa mereka adalah bagian dari sistem sosial yang harus bersinergi dengan manusia lain dan bagian dari sistem alam yang harus bersinergi dengan alam beserta seluruh isinya. Keunggulan lokal merupakan cirik khas daerah yang mencakup aspek ekonomi, budaya, teknologi informasi dan komunikasi dan ekologi yang dikembangkan dari potensi daerah. Aspek potensi pengembangan keunggulan lokal meliputi SDA, SDM, Geografis, Budaya dan Historis.

Pendidikan Berbasis Keunggulan Lokal merupakan usaha sadar yang terencana melalui penggalian dan pemanfaatan potensi daerah setempat secara arif dalam upaya mewujudkan suasana belajar dan proses pembelajaran, agar peserta didik aktif mengembangkan potensi dirinya untuk memiliki keahlian, pengetahuan dan sikap dalam upaya ikut serta membangun bangsa dan Negara khususnya dalam mencegah dari bencana Alam yang dibuat oleh manusia seperti halnya bencana asap akibat pembakaran dan pengeksploitasian hutan secara ekstrim dan liar.

PBKL di sekolah adalah pendidikan/program pembelajaran yang diselenggarakan sesuai dengan kebutuhan daerah, dengan memanfaatkan berbagai sumber daya alam, sumber daya manusia, geografis, budaya, historis dan potensi daerah lainnya yang bermanfaat dalam proses pengembangan kompetensi sesuai dengan potensi, bakat dan minat peserta didik.

Selanjutnya, Tim PBKL Kemendiknas (2011) menguraikan hasil analisis mereka tentang penentuan jenis keunggulan lokal dalam implementasinya di sekolah dalam pembelajaran, yang meliputi: inventarisasi aspek potensi keunggulan lokal, analisis kondisi internal sekolah, analisis lingkungan eksternal sekolah, dan strategi penyelenggaraan PBKL. Inventarisasi aspek potensi keunggulan lokal, dilakukan dengan:

1. Mengidentifikasi semua potensi keunggulan daerah pada setiap aspek potensi (SDA, SDM, Geografi, Sejarah, Budaya)

2. Memperhatikan potensi keunggulan lokal di kabupaten/kota yang merupakan keunggulan kompetitif dan komparatif.

3. Mengidentifikasi dan mengumpulkan informasi melalui dokumentasi, observasi, wawancara, atau literatur.

Mengelompokkan hasil identifikasi setiap aspek keunggulan lokal yang saling terkait. Setelah melakukan 
Rian Vebrianto dan Zarkasih: Education Of Local Wisdom...

inventarisasi aspek potensi keunggulan lokal dilakukan langkah kedua, yaitu menganalisis kondisi internal sekolah, yaitu:

1. Mengidentifikasi data riil internal sekolah meliputi peserta didik, diktendik, sarpras, pembiayaan dan program sekolah.

2. Mengidentifikasi kekuatan dan kelemahan sekolah yang dapat mendukung pengembangan potensi keunggulan lokal yang telah diidentifikasi.

3. Menjabarkan kesiapan sekolah berdasarkan hasil identifikasi dari kekuatan dan kelemahan sekolah yang telah dianalisis.

Langkah ketiga dalam penentuan jenis keunggulan lokal adalah dengan melakukan analisis lingkungan eksternal sekolah, yaitu:

1. Mengidentifikasi data riil lingkungan eksternal sekolah meliputi komite sekolah, dewan pendidikan, dinas/instansilain, DU/DI.

2. Mengidentifikasi peluang dan tantangan yang ada dalam pengembangan potensi keunggulan lokal yang telah diidentifikasi.

3. Menjabarkan kesiapan dukungan pengembangan

PBKL berdasarkan hasil identifikasi dari peluang dan tantangan sekolah yang telah dianalisis.

Di samping itu, dalam melakukan analisis lingkungan eksternal sekolah perlu memperhatikan tiga hal yaitu; (1) tema keunggulan lokal, (2) penetapan jenis keunggulan lokal, dan (3) kompetensi keunggulan lokal. Dalam tema keunggulan lokal, harus diperhatikan bahwa:

(a) Tema keunggulan lokal diartikan sebagai pokok pikiran atau ide pokok dari keunggulan lokal yang akan dilaksanakan pada satuan pendidikan,

(b) Kemungkinan mendapat lebih dari pada 1 tema dapat terjadi. Dipilih yang sangat potensial; paling kuat keterkaitannya dengan kesiapan sekolah dan dukungan eksternal sekolah,

(c) Tema sebagai sebuah label harus mampu menginspirasi serta memotivasi warga sekolah melakukan suatu perubahan yang membuat iklim dan budaya sekolah sesuai dengan tema yang telah ditentukan,

Landasan utama pengembangan model pendidikan berbasis keunggulan lokal Keadaan daerah dapat digambarkan dengan Tabel dibawah ini: 
Tabel 1. Landasan utama Pengembangan model pendidikan berbasis BKLK

\begin{tabular}{|c|c|c|c|}
\hline NO & Keadaan & Uraian Penjelasan/Deskripsi & FASE dalam pelaksanaan \\
\hline 1 & $\begin{array}{l}\text { Lingkungan } \\
\text { Alam }\end{array}$ & $\begin{array}{l}\text { Linkungan hidup mencakup tumbuhan, } \\
\text { hewan, dan manusia } \\
\text { Linkungan tak hidup serta peristiwa- } \\
\text { peristiwa (fisis dan biologis) yang terjadi di } \\
\text { dalamnya. mencakup tanah (daratan), air } \\
\text { (sungai, danau, dan laut), dan udara. } \\
\text { Lingkungan tak hidup dijadikan tempat } \\
\text { hidup tanaman, hewan, dan manusia. } \\
\text { Berdasarkan peta geografisnya lingkungan } \\
\text { alam mencakup pantai, dataran rendah, } \\
\text { dataran tinggi, dan pegunungan/gunung. }\end{array}$ & $\begin{array}{l}\text { Fase exploration (anak } \\
\text { mengexplore alam dengan } \\
\text { pemahamannya), invention } \\
\text { (anak memandingkan } \\
\text { pemahaman dan pengetahuan } \\
\text { barunya tentang sains } \\
\text { sehingga menimbukan ide-ide } \\
\text { yang baru dan menarik), dan } \\
\text { discovery (menghasilkan } \\
\text { pemahaman yang mantap) }\end{array}$ \\
\hline 2 & $\begin{array}{l}\text { Lingkungan } \\
\text { Sosial }\end{array}$ & $\begin{array}{l}\text { Lingkungan yang mencakup hubungan } \\
\text { timbal-balik (interaksi) antar manusia } \\
\text { sesuai dengan peraturan-peraturan yang } \\
\text { berlaku di lingkungan tersebut, serta } \\
\text { adanya sistem kemasyarakatan yang } \\
\text { dikembangkan agar terwujud suatu } \\
\text { bentuk kehidupan yang saling mengakui } \\
\text { keberadaan masing-masing anggota } \\
\text { dengan layak baik sebagai individu } \\
\text { maupun kelompok. }\end{array}$ & $\begin{array}{l}\text { Fase exploration (anak } \\
\text { mengexplore hubungan dan } \\
\text { komunikasi sosial dengan } \\
\text { pemahamannya), invention } \\
\text { (anak memandingkan } \\
\text { pemahaman dan pengetahuan } \\
\text { barunya tentang sains } \\
\text { sehingga menimbukan ide-ide } \\
\text { yang baru dan menarik), dan } \\
\text { discovery (menghasilkan sikap } \\
\text { toleransi dan saling memhami) }\end{array}$ \\
\hline 3 & $\begin{array}{l}\text { Lingkungan } \\
\text { Budaya }\end{array}$ & $\begin{array}{l}\text { Mencakup segenap aspek budaya. yang } \\
\text { dimiliki masyarakat di suatu daerah tertentu. } \\
\text { Termasuk di dalamnya antara lain: } \\
\text { Kebiasaan kebiasaan, } \\
\text { adat-istiadat, } \\
\text { aturan-aturan yang umumnya tidak tertulis } \\
\text { (misalnya tata krama, tata cara pergaulan } \\
\text { dengan orang tua sendiri atau orang lain } \\
\text { yang usianya lebih tua, pergaulan dengan } \\
\text { teman sebaya dan tetangga), nilai-nilai hasil } \\
\text { karya manusia sebagai hasil penggunaan } \\
\text { teknologi tradisional dan modern, serta } \\
\text { penampilan perlambang atau simbol-simbol } \\
\text { yang menyatakan perasaan (misalnya } \\
\text { upacara adat/tradisional), bahasa daerah } \\
\text { (misalnya tutur kata), dan kesenian daerah } \\
\text { (misalnya tari-tarian daerah), dan } \\
\text { sebagainya. }\end{array}$ & $\begin{array}{l}\text { Fase exploration (anak } \\
\text { mengexplore budaya dan nilai } \\
\text { nilai lokal yang berkembang } \\
\text { dengan pemahamannya), } \\
\text { invention (anak } \\
\text { memandingkan pemahaman } \\
\text { dan pengetahuan barunya } \\
\text { tentang sains dan budaya serta } \\
\text { nilai moral yang } \\
\text { terintegrasikan sehingga } \\
\text { menimbukan ide-ide yang } \\
\text { baru dan menarik), dan } \\
\text { discovery (menghasilkan } \\
\text { pemahaman akan sejarah, } \\
\text { geografis dan sains dalam satu } \\
\text { kesatuan pemahaman yang } \\
\text { holistik) }\end{array}$ \\
\hline
\end{tabular}

Kesimpulan
Berdasarkan kebutuhan daerah dengan pertimbangan landasan alam, sosial dan budaya maka akan ditemukan inti dari sebuah kearifan/keunggulan dari daerah tersebut yang menjadikan ciri khas dan ketinggian budaya dan sosial suatu masyarakat yang sesuai dengan nilai nilai ilmiah yang berrguna untuk menjaga pelestarian alam yang harus diwariskan keanak cucu. Sehingga menghindarkan bencana dan kerusakan hutan yang akibatnya juga bisa langsung berimpak dan berefek kepada penduduk setempat dan masyarakat. 
Kearifan lokal merupakan sebuah sistem dalam tatanan kehidupan sosial, politik, budaya, ekonomi, serta lingkungan yang hidup di tengahtengah masyarakat lokal. Ciri yang melekat dalam kearifan tradisional adalah sifatnya yang dinamis, serta ulama (memelihara umat dengan ajaran dan nilai Islam). Malah tanpa sadar kebijaksanaan melayu tentang hutan larangan berarti juga merupakan penemuan ilmu sains kelestarian lingkungan. Mereka mempunyai peranan masingmasing dalam masalah melestarikan lingkungan hidup (Husni Tamrin, 2013; vebrianto 2017).

Berbeda dengan model pembelajaran reguler yang lebih banyak memberi kesempatan kepada guru dalam menyampaikan materi pelajaran secara jelas dan terperinci. Ketika berjalannya jam pelajaran, peran guru sangat dominan di dalam kelas. Peran siswa di sini lebih banyak mendengarkan penjelasan guru, sehingga siswa sangat pasif dalam kegiatan pembelajaran. Meskipun pada pembelajarannya siswa diberikan kreativitas dengan melakukan eksperimen, tetap saja siswa tidak dapat menuangkan ide yang dimilikinya. Hal ini dikarenakan guru telah mendisain praktikumnya dan siswa hanya ditunntut untuk mencari jawaban atas persoalan yang diberikan guru.

Penerapan model pembelajaran berbasis budaya di dalam kelas, yaitu (1) menggali ide/gagasan dan keyakinan siswa melalui bertanya, (2) meneliti gagasan dan ide siswa dari berbagai perspektif (ilmiah, sains asli/tradisi, sejarah) dengan bantuan Lembaran Kerja Siswa

\footnotetext{
elaborasi

yaitu
}
(LKS),
(3) melakukan

menghubungkan konsep yang dipelajari dengan konsep/ide / keyakinan awal siswa serta menuntun siswa untuk melintasi batas budayanya menuju konsep ilmiah, dan (4) melakukan konfirmasi atau mengecek ide-ide yang cocok dan yang berbeda. Bila konsepsi awal atau keyakinan siswa tidak bertemu maka dibiarkan berjalan secara bersama-sama, dan bila ada pertemuan maka akan saling diperkuat. Dengan demikian, tidak ada ide/keyajinan (budaya lokal) yang tidak penting yang harus dihilangkan begitu saja, tetapi tetap berjalan seirama. (5) dapat turut serta menjaga lingkungan dan pelestarian hutan.

Model pembelajaran reguler lebih menekankan pada aktivitas guru (teacher centered). Langkah pembelajaran dengan menggunakan model pembelajaran reguler yaitu: (1) penyajian materi pelajaran oleh guru secara jelas dan terperinci, (2) siswa melakukan percobaan berdasarkan petunjuk LKS dan bimbingan guru, dan (3) kegiatan diskusi yang dipimpin oleh guru. Berdasarkan hal ini, proses belajar sebagian masih merupakan tanggung jawab guru. Meskipun dalam pembelajaran reguler digunakan metode selain ceramah seperti praktikum dan dilengkapi atau didukung dengan penggunaan media, penekanannya tetap pada proses penerimaan pengetahuan (materi pelajaran) bukan pada proses pencarian dan konstruksi pengetahuan. Hal ini mengakibatkan siswa tidak dapat mengaplikasikan pengetahuan yang mereka miliki ke dalam aktivitas nyata sehingga proses pembelajaran menjadi lebih bermakna. 
Beberapa kendala dan tantangan yang dialami guru dalam melaksanakan pembelajaran berbasis budaya adalah dalam memperkenalkan istilah-istilah budaya lokal khususnya bagi siswa yang bukan orang asli atau anak "kota" mengalami kesulitan. Meskipun demikian, guru menjelaskan secara ringkas istilah-istilah yang baru bagi siswa untuk meningkatkan pengetahuan dan kecintaan terhadap kebudayan lokal milik kita bersama

\subsection{Pendidikan berbasis kearifan Lokal di}

\section{Luar Sekolah}

Dari nilai dan ajaran Islam, orang Melayu mengetahui bahwa tiap manusia dikawal atau diawasi oleh Malaikat. Dukun Melayu membuat analogi bahwa tiap makhluk hidup tentu juga ada penjaganya, ini berujung dengan tetap terlestarikannya lingkungan dan alam dari pihakpihak yang berniat untuk merusak dan merampas lestarinya alam untuk anak cucu kita.

Dari akibat asap yang nyata pada tahun tahun belakangan ini, membuaty masyarakat secara tidak langsung menjadi semakin cerdas dan bijak dalam menghadapi isu asap dan kerusakan alam lainnya. Mereka kini lebih berfikir untuk masa depan dan berkembangnya anak cucu dimasa yang akan datang. Apakah pelestarian hutan ini akan menjadi sebuah warisan yang dibanggakan atau habis luluh lantak akibat keserakahan sebagian manusia.

Berdasarkan hasil dari penganalisisan secara mendalam diketahui bahwa kearifan lokal memainkan peran yang penting dalam masyarakat untuk menjaga kelestarian hutan yaitu tahap perencanaan, design dan aplikasi serta tindak lanjut. Hasil setiap tahap pengembangan dapat dijelaskan sebagai berikut: 
Tabel 2. Ulasan hasil dan pembahasan

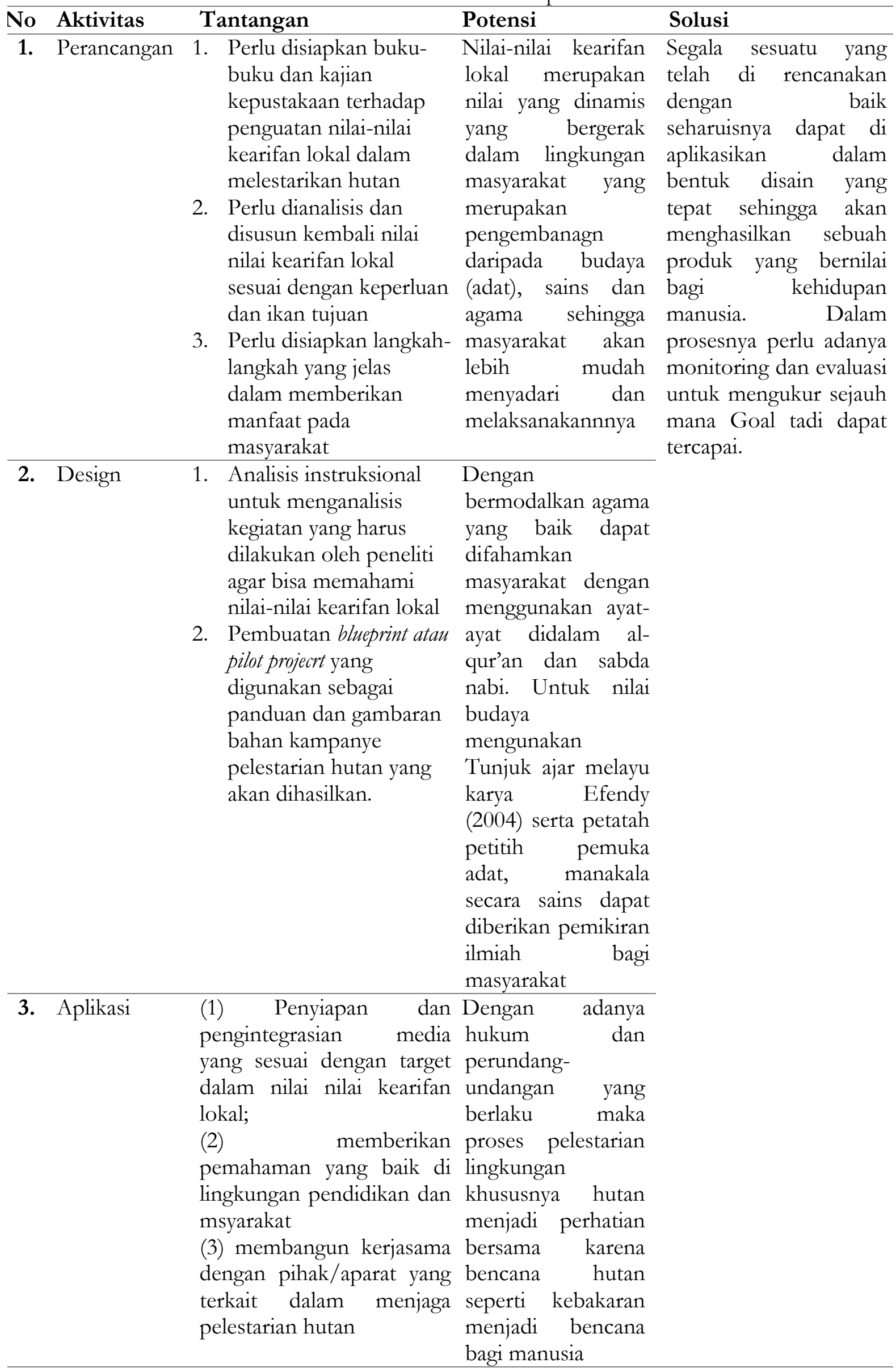




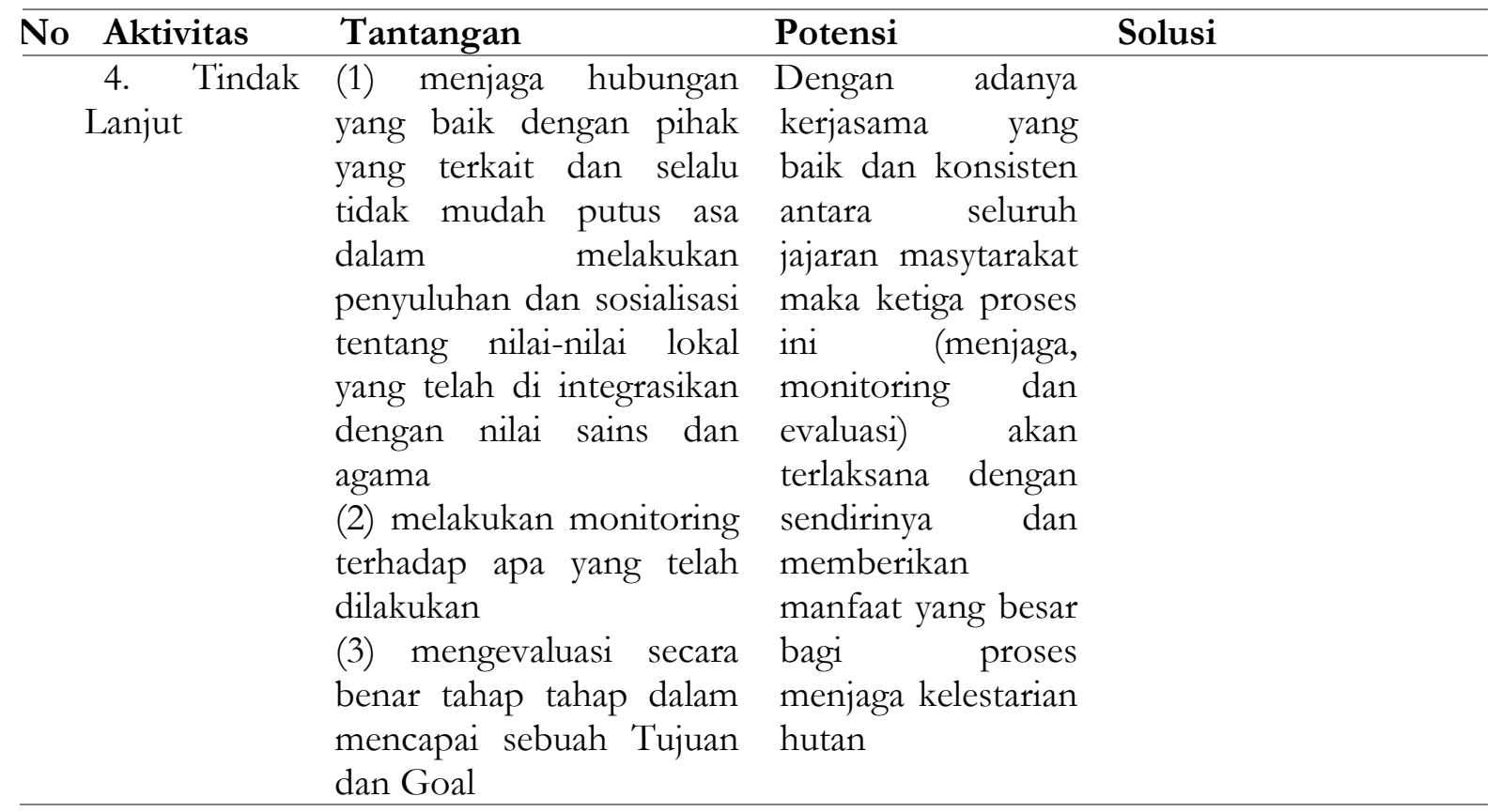

\section{PENUTUP}

\section{Simpulan}

Dari ungkapan petatah petitih di atas nampak jelas ungkapan Melayu tentang pelestarian lingkungan hidup penuh dengan nilai nilai budaya lokal (adat), sains dan agama. Nilai pelestarian lingkungan dalam ungkapan Melayu di atas pada hakikatnya terjadi simbiosis antara nilai nilai budaya dan nilai-nilai agama Islam serta sains. Kerena Islam dan Melayu merupakan dua sisi mata uang yang tak terpisahkan dan secara tidak langsung orang melayu cerdas-cerdas dalam mengelola Alam yang merupakan aplikasi keilmuan dari sains dalam mengelola dan melestarikan lingkungan. Untuk itu peranan dari kearifan lokal sangat perlu dijaga dan direvitalisasi dan di eksplore agar masyarakat dapat memahami dan mengamalkannya untuk dapat menjaga kelestarian Hutan.
Hutan yang lestari akan memberikan manfaat yang baik bagi kehidupan haiwan dan fauna termasuk manusia yang hidup di dalamnya.

\section{Saran}

Salah satu cara yang paling bijak untuk dimasukan kedalam kurikulum disekolah dan diaplikasikan diluar sekolah. Hal ini menjadi keterkaitan yang menarik untuk tetap menjaga agar hutan kita tetap lestari dan memberikan lebih banyak manfaat bagi masyrakat yang tinggal di dekatnya atas oksigen, kejernihan air, dan jauhnya dari bencana banjir dan tanah longsor. Merupakan faktor faktor yang harus diingat dan dijadikan pedoman dalam menjaga dan melesatrikan hutan. Malahan kedepan hutan dapat dijadikan objek wisata yang sangat menarik dan indah yang dapat memberikan berbagai nilai postif bagi kehidpan manusia. 
Rian Vebrianto dan Zarkasih: Education Of Local Wisdom...

\section{DAFTAR PUSTAKA}

Alqur'an dan Terjemahannya.

Ayatrohaedi.1986. Kepribadian Budaya Bangsa (local Genius), Pustaka Jaya, Jakarta.

Erwan Baharudin.2012.Kearifan Store, Pengetahuan Degradasi Lingkungan

Http://www.esaunggul.ac.id/epaper/kearifanlokal-pengetahuan-lokal-dan-degradasilingkungan/ [20 Agustus 2017]

George, J. 1995. An analysis of traditional practices and beliefs in a Trinidadian village to access the implications for science education, St Augustine, , West Indies: The University of the West Indies. Unpublished doctoral dissertation [Google Scholar]

Hadis nabi dan terjemahannya

Herbert, S. 2008. Collateral Learning in Science: Students' responses to a cross-cultural unit of work. International journal of science Education Volume 30, issues 7

Husni Thamrin. 2013. Kearifan Lokal dalam Pelestarian Lingkungan (Kebijaksanaan Lokal dalam Lingkungan yang Berkelanjutan) Kutubkhanah, Vol. 16 No. 1

Lawson, Anton E. (1995). Science Teaching and Development of Thinking. Belmont: Wadsworth Publishing Company.

Republika. 2015. bttp://m.republika.co.id. Diakses tanggal 26 Desember 2015.

Sentosa, Harry. 2015. Fitrah Based Education. Bekasi: Yayasan Cahaya Mutiara Timur.

Suyanto, unna chokkalingam dan Prianto Wibowo. 2003. Kebakaran lahan Rawa/Gambut di sumatera: Masalah dan Solusi. Prosiding semiloka ; Palembang. Center for international forestry Research.

Syaufina, L Dan Fransisxo GS Tambunan 2013. Kearifan Lokal Masyarakat dalam Pencegahan Kebakaran Tanah dan Hutan
(Studi Kasus Komunitas Lokal Kasepuhan Ciptagelar, Desa Sirnaresmi Kecamatan Cisolok, Kabupaten Sukabumi, Provinsi Jawa Barat). Tropisme J. Silvikultur. Vol. 04 No. 3 Desember 2013, Hal. 166 -170. ISSN: 2086-8227

Tenas Effendi. 2004. Tunjuk ajar melayu (butir-butir budaya melayu Riau). Yogyakarta: Balai Kajian Day Pengembangan Budaya

Tisrin. 2015. Modul lingkungan berbasi islam dan sains. Thesis. Medan

Vebrianto 2017. Riau Jamrud Khatulistiwa: harapan dan Tantang. Surat kepada Gubernur. Pekanbaru.

Vebrianto, R., \& Osman. K. 2011.Keberkesanan Penggunaan Media Berasaskan Alam Sekitar Dalam Meningkatkan Kemahiran Proses Sains Dan Pencapaian Pelajar. Seminar Serantau V, Pekanbaru, Indonesia. 